\title{
Naïve Bayes and SMART to Determine Toddler Development and Status
}

\author{
Qomariah Kumala Dewi ${ }^{1 *}$, Imam Husni Al Amin ${ }^{2 * *}$ \\ * Informatics Engineering, Stikubank University \\ ** Faculty of Information Technology, Stikubank University \\ qomariahkd10@gmail.com ${ }^{1}$,imam@edu.unisbank.ac.id ${ }^{2}$
}

\begin{tabular}{l} 
Article Info \\
\hline Article history: \\
Received 26-06-2021 \\
Revised 19-07-2021 \\
Accepted 22-07-2021 \\
\hline Keyword: \\
Nä̈ve Bayes Classifier, \\
Simple Multi Attribute Rating \\
Technique (SMART), \\
Posyandu, Status Decision \\
Toddler Support System. \\
Supp
\end{tabular}

\begin{abstract}
Integrated Service Post (Posyandu) is a forum used for health services carried out from and for the community under the guidance of health workers. Currently, toddlers need to be given more attention to monitor their growth and development. The number of children under five who are monitored by posyandu cadres and puskesmas officers will certainly take a lot of time and require maximum accuracy in classifying the status of each toddler. The purpose of the design of this decision support system is to assist posyandu cadres in determining the developmental decisions of active and inactive toddlers. This research is very important to assist posyandu cadres in providing proper analysis of the developmental status of each toddler. The results of this study are an application that can be used to determine the criteria for growth and development of toddlers using the Naive Bayes and SMART methods so that they can help posyandu cadres in determining the development of toddler status.
\end{abstract}

\section{INTRODUCTION}

Integrated Service Post (Posyandu) is a place for health services carried out from and for the community and fostered by health workers. Posyandu is one of the Community-Based Health Efforts (UKBM). Posyandu is held regularly every month in every posyandu place. Karya Harapan Mukti Village has four posyandu places that are actively used every month.

Currently, the priority in obtaining posyandu services is children under five. Age Under Five Years (toddlers) is a period that needs to be monitored for growth and development. Toddler growth can be seen from the outside such as weight, height and head circumference. While the development of toddlers cannot be seen from the outside because it involves the process of emotional and mental changes from toddlers. For this reason, it is necessary to carry out monthly monitoring of toddlers.

In an effort to improve the growth and development of good toddlers, it is necessary to have the role of posyandu cadres in providing appropriate counseling and in accordance with the case of each toddler. Problems of growth and development in toddlers will be classified into the developmental status of toddlers. The developmental status of toddlers is divided into active status and inactive status. Posyandu cadres will classify the developmental status of toddlers using two criteria, namely growth criteria and development criteria.

The process of determining the developmental status of children under five made by posyandu cadres is still manual, so it is vulnerable to errors made by humans. Therefore, a decision support system is needed to assist posyandu cadres in determining the developmental status of toddlers. This application will be built using the Naive Bayes Classifier method and the Simple Multi Attribute Rating Technique (SMART) to get the results of the decision on the developmental status of active or inactive toddlers.

The existence of classification and ranking in decision making can determine the quality of the data which is an important factor in the success of forecasting[1][2][3]. The application of the Simple Multi Attribute Rating Technique (SMART) method can be used to rank the growth and development of toddlers, nutritional status of toddlers, student assessments and assessment of vulnerability to BLAST based on predetermined weights and criteria[4][5][6][7]. While the Naïve Bayes (NB) method can be used to classify tweet feeds into negative or positive polarity classes, but still has low accuracy. Based on the 
evaluation results using the confusion matrix, it is evident that the results of Naive Bayes with PSO for election sentiment analysis are $90.74 \%$ [8].

Based on this background, this research is very important to assist posyandu cadres in providing an appropriate analysis of the developmental status of each toddler. The analysis of decision-making on the developmental status of children under five aims to create a generation of toddlers who grow and develop better. With the growth and development criteria applied to the Naive Bayes and SMART methods, it can provide decisions about the status of active and inactive development in toddlers.

\section{RESEARCH METHODS}

The type of data that will be used in this research is primary data. Primary data is data obtained directly from the object of research. This research was conducted in Karya Harapan Mukti Village, Bungo Regency, Jambi Province. Where the data obtained will be used in determining the developmental status of toddlers. In this section, we will discuss the methods that will be used in the research. The Naive Bayes method will be used to determine the classification of active and inactive status in toddlers. Meanwhile, the Simple Multi-Attribute Rating Technique (SMART) method will be used to rank children under five based on the highest final result.

\section{A. Naive Bayes Classifier Method}

1. Definition of Naive Bayes Classifier Method

Nave Bayes classifier is a classification method based on Bayes' theorem. The main feature of the Nave Bayes classifier is the assumption of a strong independence from the conditions. Classification with statistical models to calculate the probability of a class for each existing attribute group, and determine which class is optimal. The Bayes method gives the probability of an event based on previous information[3][9].

\section{Naive Bayes Classifier Method Calculation Concept}

There are stages of the process in performing calculations using the Naïve Bayes method, namely[10]:

1) Counting the number of classes/labels.

2) Counting the number of cases per class.

3) Multiply all class variables.

4) Comparing

The formula that will be used to find the results of the Naïve Bayes Classifier classification is[10]:

$$
P(A \mid B)=\frac{P(B \mid A) * P(A)}{P(B)}
$$

Information:

- $\quad \mathrm{P}(\mathrm{A} \mid \mathrm{B}) \quad$ : probability of $\mathrm{A}$ and $\mathrm{B}$ occurring together

- $\mathrm{P}(\mathrm{B} \mid \mathrm{A}) \quad$ : probability of $\mathrm{B}$ and $\mathrm{A}$ occurring together

- $\mathrm{P}(\mathrm{A}) \quad$ : probability of event A

- $\mathrm{P}(\mathrm{B}) \quad$ : probability of event B

\section{B. Simple Multi Attribute Rating Technique (SMART)}

1. Definition of Simple Multi Attribute Rating Technique (SMART)

The SMART method is multi-attribute decision making. This decision-making technique is used to assist stakeholders in choosing among several alternatives. Each alternative consists of a set of attributes, and each attribute has an average value with a certain scale. Each attribute has a weight to be used as a benchmark in determining an alternative that is considered the best for a particular problem[11][4].

\section{Simple Multi Attribute Rating Technique (SMART)}

Calculation Concept

Each criterion is given a value and weight or has a value and weight to be used as a benchmark in determining an alternative that is best assessed on a particular problem[4].

The formula that will be used to find the results of the SMART method is as follows.

$$
u i(a i)=\sum_{J=1}^{m} W j U i(a i) \quad \mathrm{i}=1,2, \ldots . . \mathrm{m}
$$

Information:

- wj : : weighting value of criteria $\mathrm{j}$ and $\mathrm{k}$ criteria

- ui(ai) : utility value of criterion i for criterion $\mathrm{i}$

With the Simple Multi Attribute Rating Technology (SMART) method, attribute weighting is carried out in two steps, namely[7]:

1) Determine the number of criteria and weights to be used in the study

2) Normalization of criteria

To find the normalization of each criterion can use the formula below.

$$
\text { Normalization }=\frac{W j}{\sum W j}
$$

Information:

$\begin{array}{ll}\mathrm{w}_{\mathrm{j}} & \text { : weight of a criterion } \\ \sum \mathrm{w}_{\mathrm{j}} \quad \text { : total weight of all criteria }\end{array}$

3) Utility value search

To find the utility value use the following formula.

$u i(a i)=100 \frac{\text { Cout } i-C \min }{\text { Cmax }- \text { Cmin }} \%$

Information:

$\mathrm{u}_{\mathrm{i}}\left(\mathrm{a}_{\mathrm{i}}\right)$ : utility value of criterion $\mathrm{i}$ for criterion $\mathrm{i}$

Cmax : maximum criterion value

Cmin : the value of the manimal criteria

Cout $_{i}$ : criterion value

4) Looking for the results of each criterion

5) Search the final result of the SMART method

The method used in the decision support system process to determine the development of the status of active and 
inactive toddlers during the posyandu is the Naïve Bayes Classifier and the Multi Attribute Rating Technique (SMART) system. Below are the stages in the research that is being made.

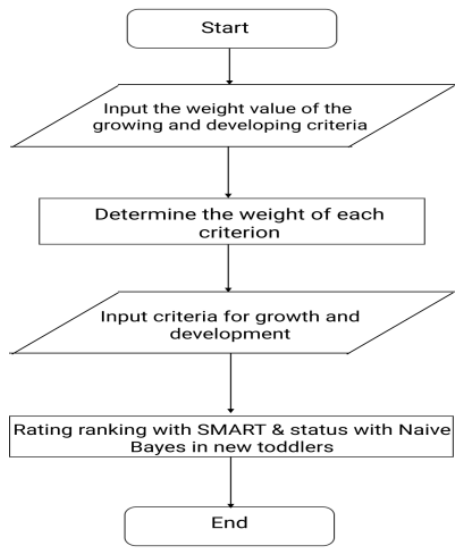

Figure 1. Research Stages

Figure 1 describes the flow of a decision support system for determining developmental decisions and toddler status. Starting with start, input the weight value of the growing and developing criteria, determining status using the Naive Bayes Classifier method and ranking using the SMART method, ending with end.

In this study, the design of this system is described using a use case diagram. The use case diagram will explain the functions that will be performed by each user. Figure 2 shows a use case diagram on a decision support system for determining the developmental status of toddlers.

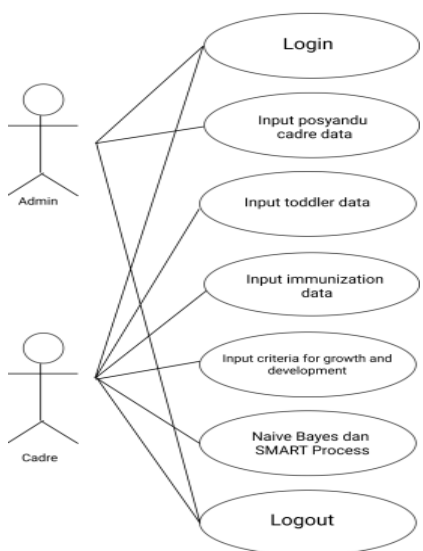

Figure 2. Use Case Diagram

The role of the admin is to add posyandu cadre data into the system. Meanwhile, the role of posyandu cadres is to input toddler data, input toddler immunization data, input criteria results, and the process of determining toddler decisions.

\section{RESULT AND DESCUSSION}

Implementation of a Decision Support System to determine the developmental status of toddlers includes inputs and outputs. Input in the form of filling in toddler data, immunization data and status data from the results of calculations using the Naive Bayes and SMART methods with the stages of calculating growth and development criteria. The output of this decision support system is the ranking and the results of decisions on active or inactive status in toddlers.

\subsection{Determination of Criteria}

This study will determine the results based on the ranking and status of children under five using the SMART method and the Naive Bayes Classifier using the following criteria:

1. Growing: weight gain ( $\mathrm{t} 1)$, height increased $(\mathrm{t} 2)$, head circumference increased (t3) and cheerful, growing and lively (t5).

2. Developing: shows age-appropriate movement (b1), age-appropriate speech (b2), reaches age-appropriate developmental milestones (b3), can respond to objects/colors (b4) and can respond to sound (b5).

\subsection{Calculation Analysis of The Nä̈ve Bayes Classifier Method}

The steps for implementing the Naïve Bayes Classifier method into a decision support system are:

1) Counting the number of classes/labels.

The criteria code data in table 1 will be used for calculations using the Naïve Bayes method.

TABEL I

CRITERIA CODE NAMES AND VALUES

\begin{tabular}{|c|l|c|}
\hline \multirow{2}{*}{ Code } & \multicolumn{1}{|c|}{ Criteria Name } & Value \\
\hline \multirow{2}{*}{ b1 } & Shows age-appropriate movemnets & 0 \\
\cline { 3 - 3 } & & 1 \\
\hline \multirow{2}{*}{ b2 } & Age-appropriate speech & 0 \\
\cline { 3 - 3 } & Reach age-appropriate & 1 \\
\hline \multirow{2}{*}{ b4 } & developmental milestones & 0 \\
\hline \multirow{2}{*}{ b5 } & Can respond to objects/colors & 1 \\
\cline { 3 - 3 } & Can respond to sound & 1 \\
\cline { 3 - 3 } & & \\
\hline
\end{tabular}

The criteria data in table 1 is used to classify the final results of the Naïve Bayes Classifier method which will be classified into active and inactive status.

TABEL II

STATUS CODE NAMES

\begin{tabular}{|c|c|}
\hline Code & Status \\
\hline $\mathrm{s} 1$ & Active \\
\hline $\mathrm{s} 2$ & Inactive \\
\hline
\end{tabular}

The following is a training table from the Posyandu dataset. This dataset contains 8 data consisting of 5 parts of developing criteria. 
TABEL III

TRAINING DATA

\begin{tabular}{|c|c|c|c|c|c|c|}
\hline \multirow{2}{*}{ No } & \multicolumn{7}{|c|}{ Criteria Code } & \multirow{2}{*}{ Status } \\
\cline { 2 - 6 } & $\mathbf{b 1}$ & $\mathbf{b 2}$ & $\mathbf{b 3}$ & $\mathbf{b 4}$ & $\mathbf{b 5}$ & \\
\hline 1 & 1 & 1 & 1 & 1 & 1 & Active \\
\hline 2 & 0 & 1 & 1 & 1 & 1 & Active \\
\hline 3 & 0 & 1 & 0 & 1 & 1 & Inactive \\
\hline 4 & 0 & 0 & 0 & 1 & 1 & Inactive \\
\hline 5 & 1 & 1 & 0 & 1 & 1 & Inactive \\
\hline 6 & 1 & 0 & 1 & 1 & 1 & Active \\
\hline 7 & 1 & 0 & 0 & 1 & 1 & Inactive \\
\hline 8 & 0 & 0 & 1 & 1 & 1 & Active \\
\hline
\end{tabular}

To solve this problem, the classification calculation process is carried out using the Naive Bayes method using available training data.

2) Counting the number of cases per class.

The criteria value data in this study will be used to find the calculation of the classification of the developmental status of toddler. The data can be seen in table 4 .

TABEL IV

VALUE OF TODDLER CRITERIA

\begin{tabular}{|c|l|c|c|c|c|c|}
\hline \multirow{2}{*}{ No } & \multirow{2}{*}{ Name } & \multicolumn{5}{|c|}{ Developing Criteria Code } \\
\cline { 3 - 7 } & & b1 & b2 & b3 & b4 & b5 \\
\hline 1 & Adam & 1 & 0 & 1 & 1 & 1 \\
\hline 2 & Rida & 1 & 1 & 1 & 1 & 1 \\
\hline 3 & Syafira & 1 & 0 & 1 & 1 & 1 \\
\hline 4 & Arvino & 1 & 0 & 1 & 1 & 1 \\
\hline 5 & Malikha & 1 & 0 & 1 & 1 & 1 \\
\hline 6 & M. Gibran & 1 & 0 & 1 & 1 & 1 \\
\hline 7 & Mikayla & 1 & 0 & 1 & 1 & 1 \\
\hline 8 & M. Abil & 1 & 0 & 1 & 1 & 1 \\
\hline 9 & Atthaya & 1 & 0 & 1 & 1 & 1 \\
\hline 10 & Afidatul & 0 & 1 & 1 & 1 & 1 \\
\hline
\end{tabular}

The value of the existing toddler criteria will then be calculated with the same problem from the same class on the training data. The results of the calculation of the active status can be seen in table 5 of the calculation data for the development criteria.

TABEL V

ACtive Calculation Data DeVelopment CRiteria

\begin{tabular}{|c|l|c|c|c|c|c|}
\hline \multirow{2}{*}{ No } & \multirow{2}{*}{ Name } & \multicolumn{5}{|c|}{ Active Value } \\
\cline { 3 - 7 } & & b1 & b2 & b3 & b4 & b5 \\
\hline 1 & Adam & 0,5 & 0,5 & 1 & 0,5 & 0,5 \\
\hline 2 & Rida & 0,5 & 0,5 & 1 & 0,5 & 0,5 \\
\hline 3 & Syafira & 0,5 & 0,5 & 1 & 0,5 & 0,5 \\
\hline 4 & Arvino & 0,5 & 0,5 & 1 & 0,5 & 0,5 \\
\hline 5 & Malikha & 0,5 & 0,5 & 1 & 0,5 & 0,5 \\
\hline 6 & M. Gibran & 0,5 & 0,5 & 1 & 0,5 & 0,5 \\
\hline 7 & Mikayla & 0,5 & 0,5 & 1 & 0,5 & 0,5 \\
\hline 8 & M. Abil & 0,5 & 0,5 & 1 & 0,5 & 0,5 \\
\hline 9 & Atthaya & 0,5 & 0,5 & 1 & 0,5 & 0,5 \\
\hline 10 & Afidatul & 0,5 & 0,5 & 1 & 0,5 & 0,5 \\
\hline
\end{tabular}

The results from table 5 are obtained from the following calculations:

Examples of cases in toddlers (Adam)

Looking for b1 value, 1 value with active status

$b 1 \mid 1=\frac{2}{4}=0,5$

Looking for b2 value, 0 value with active status $b 2 \mid 0=\frac{2}{4}=0,5$

Looking for b3 value, 1 value with active status $b 3 \mid 1=\frac{4}{4}=1$

Looking for b4 value, 1 value with active status $b 4 \mid 1=\frac{2}{4}=0,5$

Looking for b5 value, 1 value with active status $b 5 \mid 1=\frac{2}{4}=0,5$

While the results of the calculation of inactive status can be seen in table 6 of the calculation data for the development criteria.

TABEL VI

INACTIVE CALCULATION DATA DEVELOPMENT CRITERIA

\begin{tabular}{|c|l|c|c|c|c|c|}
\hline \multirow{2}{*}{ No } & \multirow{2}{*}{ Name } & \multicolumn{5}{|c|}{ Inactive Value } \\
\cline { 3 - 7 } & & b1 & b2 & b3 & b4 & b5 \\
\hline 1 & Adam & 0,5 & 0,5 & 0 & 0,5 & 0,5 \\
\hline 2 & Rida & 0,5 & 0,5 & 0 & 0,5 & 0,5 \\
\hline 3 & Syafira & 0,5 & 0,5 & 0 & 0,5 & 0,5 \\
\hline 4 & Arvino & 0,5 & 0,5 & 0 & 0,5 & 0,5 \\
\hline 5 & Malikha & 0,5 & 0,5 & 0 & 0,5 & 0,5 \\
\hline 6 & M. Gibran & 0,5 & 0,5 & 0 & 0,5 & 0,5 \\
\hline 7 & Mikayla & 0,5 & 0,5 & 0 & 0,5 & 0,5 \\
\hline 8 & M. Abil & 0,5 & 0,5 & 0 & 0,5 & 0,5 \\
\hline 9 & Atthaya & 0,5 & 0,5 & 0 & 0,5 & 0,5 \\
\hline 10 & Afidatul & 0,5 & 0,5 & 0 & 0,5 & 0,5 \\
\hline
\end{tabular}

The results from table 6 are obtained from the following calculations:

Examples of cases in toddlers (Adam)

Looking for b1 value, 1 value with inactive status

$b 1 \mid 1=\frac{2}{4}=0,5$

Looking for b2 value, 0 value with inactive status b2 $\mid 0=\frac{2}{4}=0,5$

Looking for b3 value, 1 value with inactive status $b 3 \mid 1=\frac{0}{4}=0$

Looking for b4 value, 1 value with inactive status $b 4 \mid 1=\frac{2}{4}=0,5$

Looking for b5 value, 1 value with inactive status $b 5 \mid 1=\frac{2}{4}=0,5$

3) Multiply all class variables.

The third step is to multiply all the variables in the developing criteria that are active. To make it easier to understand, it is written in tabular form which can be seen in table 7 . 
TABEL VII

Aactive Status Variable VALUes

\begin{tabular}{|c|c|c|c|c|c|c|c|}
\hline \multirow{2}{*}{ No } & \multirow{2}{*}{ Name } & \multicolumn{5}{|c|}{ Active } & \multirow{2}{*}{ Value } \\
\hline & & b1 & b2 & b3 & b4 & b5 & \\
\hline 1 & Adam & 0,5 & 0,5 & 1 & 0,5 & 0,5 & 0,0625 \\
\hline 2 & Rida & 0,5 & 0,5 & 1 & 0,5 & 0,5 & 0,0625 \\
\hline 3 & Syafira & 0,5 & 0,5 & 1 & 0,5 & 0,5 & 0,0625 \\
\hline 4 & Arvino & 0,5 & 0,5 & 1 & 0,5 & 0,5 & 0,0625 \\
\hline 5 & Malikha & 0,5 & 0,5 & 1 & 0,5 & 0,5 & 0,0625 \\
\hline 6 & M. Gibran & 0,5 & 0,5 & 1 & 0,5 & 0,5 & 0,0625 \\
\hline 7 & Mikayla & 0,5 & 0,5 & 1 & 0,5 & 0,5 & 0,0625 \\
\hline 8 & M. Abil & 0,5 & 0,5 & 1 & 0,5 & 0,5 & 0,0625 \\
\hline 9 & Atthaya & 0,5 & 0,5 & 1 & 0,5 & 0,5 & 0,0625 \\
\hline 10 & Afidatul & 0,5 & 0,5 & 1 & 0,5 & 0,5 & 0,0625 \\
\hline
\end{tabular}

In table 7 the value of the active status variable is obtained from the results of multiplying all the existing criteria. An example of the calculation can be seen in the case of toddler Adam below:

Value $=b 1 \times b 2 \times b 3 \times b 4 \times b 5$

$=0,5 \times 0,5, x 1 \times 0,5 \times 0,5=0,0625$

Next, multiply all the variables in the development criteria that have an inactive state. To make it easier to understand, it is written in tabular form which can be seen in table 8 .

TABEL VIII

INACTIVE STATUS VARIABLE VALUES

\begin{tabular}{|c|c|c|c|c|c|c|c|}
\hline \multirow{2}{*}{ No } & \multirow{2}{*}{ Name } & \multicolumn{5}{|c|}{ Inactive } & \multirow{2}{*}{ Value } \\
\hline & & b1 & b2 & b3 & b4 & b5 & \\
\hline 1 & Adam & 0,5 & 0,5 & 0 & 0,5 & 0,5 & 0 \\
\hline 2 & Rida & 0,5 & 0,5 & 0 & 0,5 & 0,5 & 0 \\
\hline 3 & Syafira & 0,5 & 0,5 & 0 & 0,5 & 0,5 & 0 \\
\hline 4 & Arvino & 0,5 & 0,5 & 0 & 0,5 & 0,5 & 0 \\
\hline 5 & Malikha & 0,5 & 0,5 & 0 & 0,5 & 0,5 & 0 \\
\hline 6 & M. Gibran & 0,5 & 0,5 & 0 & 0,5 & 0,5 & 0 \\
\hline 7 & Mikayla & 0,5 & 0,5 & 0 & 0,5 & 0,5 & 0 \\
\hline 8 & M. Abil & 0,5 & 0,5 & 0 & 0,5 & 0,5 & 0 \\
\hline 9 & Atthaya & 0,5 & 0,5 & 0 & 0,5 & 0,5 & 0 \\
\hline 10 & Afidatul & 0,5 & 0,5 & 0 & 0,5 & 0,5 & 0 \\
\hline
\end{tabular}

In table 8 the value of the inactive status variable is obtained from the results of multiplying all the existing criteria. An example of the calculation can be seen in the case of toddler Adam below:

$$
\text { Value }=b 1 \times b 2 \times b 3 \times b 4 \times b 5
$$$$
=0,5 \times 0,5, x 0 \times 0,5 \times 0,5=0
$$

\section{4) Comparing}

To get the active status for each toddler, the active value must be greater than the inactive value. To make it easier to compare active and inactive values, it can be seen in table 9 .
TABEL IX

TODDLER STATUS

\begin{tabular}{|c|l|c|c|c|}
\hline No & Name & $\begin{array}{c}\text { Active } \\
\text { Value }\end{array}$ & $\begin{array}{c}\text { Inactive } \\
\text { Value }\end{array}$ & Status \\
\hline 1 & Adam & 0,0625 & 0 & Active \\
\hline 2 & Rida & 0,0625 & 0 & Active \\
\hline 3 & Syafira & 0,0625 & 0 & Active \\
\hline 4 & Arvino & 0,0625 & 0 & Active \\
\hline 5 & Malikha & 0,0625 & 0 & Active \\
\hline 6 & M. Gibran & 0,0625 & 0 & Active \\
\hline 7 & Mikayla & 0,0625 & 0 & Active \\
\hline 8 & M. Abil & 0,0625 & 0 & Active \\
\hline 9 & Atthaya & 0,0625 & 0 & Active \\
\hline 10 & Afidatul & 0,0625 & 0 & Active \\
\hline
\end{tabular}

From table 9 obtained the results of the status of each toddler. Take for example the status of a toddler whose name is Adam "Active" because the value is active $>$ the value is inactive.

\subsection{Calculation Analysis of The Simple Multi Attribute Rating Technique (SMART)}

SMART is a multi-criteria decision-making technique based on the theory that each alternative consists of a number of criteria that describe how important it is compared to other criteria. The weighting is used to assess each alternative afar to obtain the best alternative.

The models used in using the SMART method are:

$$
u i(a i)=\sum_{J=1}^{m} W j U i(a i) \quad \mathrm{i}=1,2, \ldots . \mathrm{m}
$$

Information:

- wj : weighting value of criteria $\mathrm{j}$ and $\mathrm{k}$ criteria

- ui(ai) : utility value of criterion $\mathrm{i}$ for criterion $\mathrm{i}$

The steps for working on the Simple Multi Attribute Rating Technique (SMART) method are as follows:

1) Determine the number of criteria and weights to be used in the study

Before performing calculations using the SMART method, the first thing to do is determine the number of criteria and the total weight of each predetermined criterion. The first is the growth criteria which has 4 criteria. The criteria for data growth are seen in table 10 .

TABEL X

GROWING CRITERIA

\begin{tabular}{|c|c|c|}
\hline Code & Value & Weight \\
\hline $\mathrm{t} 1$ & 15 & \multirow{2}{*}{4} \\
$\mathrm{t} 2$ & 15 & \\
$\mathrm{t} 2$ & 30 & \\
$\mathrm{t} 3$ & 40 & \\
\hline
\end{tabular}

The second is the developing criteria which has 5 criteria. The data development criteria can be seen in table 11 . 
TABEL XI

DEVELOPING CRITERIA

\begin{tabular}{|c|c|c|}
\hline Code & Value & Weight \\
\hline b1 & 20 & \multirow{2}{*}{6} \\
\hline b2 & 10 & $60 \%$ \\
\hline b3 & 30 & \\
\hline b4 & 20 & \\
\hline b5 & 20 & \\
\hline
\end{tabular}

2) Normalization of criteria

The formula for finding normalization is:

$$
\text { Normalization }=\frac{W j}{\sum W j}
$$

Information:

- wj : weight of a criterion

- $\quad \sum$ wj $\quad$ : total weight of all criteria

Calculating the normalization of each criterion

a. Normalization of growth criteria $=40 \%$

$=\frac{40}{100}=0,4$

b. Normalization of developing criteria $=60 \%$ $=\frac{60}{100}=0,6$

3) Utility value search

To find the utility value of each criterion, you can use the following formula:

$$
u i(a i)=100 \frac{\text { Cout } i-\text { Cmin }}{\text { Cmax }- \text { Cmin }} \%
$$

Information:

- ui(ai) : utility value of criterion i for criterion $\mathrm{i}$

- Cmax : maximum criterion value

- Cmin : the value of the manimal criteria

- Couti : criterion value i

The results of the utility calculation for each toddler's growth criteria can be seen in the following table.

TABEL XII

\begin{tabular}{|c|c|c|c|c|c|c|c|}
\hline \multirow{2}{*}{ No } & \multirow{2}{*}{ Name } & \multicolumn{4}{|c|}{ Growing Criteria } & \multirow{2}{*}{ Couti } & \multirow{2}{*}{ Utility } \\
\hline & & t1 & t2 & t3 & t4 & & \\
\hline 1 & Adam & 1 & 1 & 0 & 1 & 70 & 65 \\
\hline 2 & Rida & 1 & 0 & 1 & 1 & 85 & 82 \\
\hline 3 & Syafira & 0 & 0 & 1 & 1 & 70 & 65 \\
\hline 4 & Arvino & 1 & 0 & 1 & 1 & 85 & 82 \\
\hline 5 & Malikha & 1 & 0 & 1 & 1 & 85 & 82 \\
\hline 6 & M. Gibran & 0 & 1 & 0 & 1 & 55 & 47 \\
\hline 7 & Mikayla & 0 & 1 & 1 & 1 & 85 & 82 \\
\hline 8 & M. Abil & 1 & 0 & 1 & 1 & 85 & 82 \\
\hline 9 & Atthaya & 1 & 0 & 0 & 1 & 55 & 47 \\
\hline 10 & Afidatul & 1 & 1 & 0 & 1 & 70 & 65 \\
\hline
\end{tabular}

VALUE UTILITY GROWING CRITERIA
To get the utility value of each toddler as shown in table 12. First look for the criterion value (Couti), to find the criterion value multiply the criterion value of each toddler in the criterion value in table 10 . Then the criterion value will be used to find the utility value of the toddler. A toddler with the name Adam would be an example of a utility value search.

$$
\underset{70}{\text { Couti }}=(1 \times 15)+(1 \times 15)+(0 \times 30)+(1 \times 40)=
$$

Cout $t_{i}$ is obtained from the calculation of the value of the criteria data multiplied by the value of the growth criteria in table 10 . Next, find the utility value.

$$
\begin{aligned}
& u i(a i)=100 \frac{\text { Cout } i-C \min }{\text { Cmax }- \text { Cmin }} \% \\
& u i(a i)=100 \frac{70-15}{100-15} \%=100 \frac{55}{85}=100 \times 0,65=65
\end{aligned}
$$

\begin{tabular}{|c|c|c|c|c|c|c|c|c|}
\hline \multirow{2}{*}{ No } & \multirow{2}{*}{ Name } & \multicolumn{5}{|c|}{ Developing Criteria } & \multirow{2}{*}{$\begin{array}{c}\text { Cout } \\
\text { i }\end{array}$} & \multirow[t]{2}{*}{ Utility } \\
\hline & & b1 & b2 & b3 & b4 & b5 & & \\
\hline 1 & Adam & 1 & 0 & 1 & 1 & 1 & 90 & 89 \\
\hline 2 & Rida & 1 & 1 & 1 & 1 & 1 & 100 & 100 \\
\hline 3 & Syafira & 1 & 0 & 1 & 1 & 1 & 90 & 89 \\
\hline 4 & Arvino & 1 & 0 & 1 & 1 & 1 & 90 & 89 \\
\hline 5 & Malikha & 1 & 0 & 1 & 1 & 1 & 90 & 89 \\
\hline 6 & $\begin{array}{l}\text { M. } \\
\text { Gibran }\end{array}$ & 1 & 0 & 1 & 1 & 1 & 90 & 89 \\
\hline 7 & Mikayla & 1 & 0 & 1 & 1 & 1 & 90 & 89 \\
\hline 8 & M. Abil & 1 & 0 & 1 & 1 & 1 & 90 & 89 \\
\hline 9 & Atthaya & 1 & 0 & 1 & 1 & 1 & 90 & 89 \\
\hline 10 & Afidatul & 0 & 1 & 1 & 1 & 1 & 80 & 78 \\
\hline
\end{tabular}

Find the utility value of the development criteria of each toddler as shown in table 13 .

TABEL XIII

VAlue UTILITY DEVELOPING CRITERIA

And to get the utility value of each toddler as shown in table 13. First look for the criterion value (Couti), to find the criterion value multiply the criterion value of each toddler with the criterion value in table 11 . Then the criterion value will be used to find the utility value toddler. A toddler with the name Adam would be an example of a utility value search.

$$
\begin{aligned}
& \text { Couti }=(1 \times 20)+(0 \times 10)+(0 \times 30)+(1 \times 20)+ \\
& (1 \times 20)=90
\end{aligned}
$$

Couti is obtained from the calculation of the value of the criteria data multiplied by the value of the developing criteria in table 11 . Next, find the utility value.

$$
\begin{aligned}
& u i(a i)=100 \frac{\text { Cout } i-C \min }{\text { Cmax }-C \min } \% \\
& u i(a i)=100 \frac{90-10}{100-10} \%=100 \frac{80}{90}=100 \times 0,89=89
\end{aligned}
$$


4) Looking for the results of each criterion

The results of the search for the utility of growth criteria in table 12 will be used to search for the normalization value of the growth criteria of each toddler. The results of normalization can be seen in table 14 .

TABEL XIV

GROWING CRITERIA RESULTS

\begin{tabular}{|c|l|c|c|c|}
\hline \multirow{2}{*}{ No } & \multirow{2}{*}{ Name } & \multicolumn{3}{|c|}{ Growing Criteria } \\
\cline { 3 - 5 } & & Utility & Normalization & Results \\
\hline 1 & Adam & 65 & 0,4 & 26 \\
\hline 2 & Rida & 82 & 0,4 & 32,8 \\
\hline 3 & Syafira & 65 & 0,4 & 26 \\
\hline 4 & Arvino & 82 & 0,4 & 32,8 \\
\hline 5 & Malikha & 82 & 0,4 & 32,8 \\
\hline 6 & M. Gibran & 47 & 0,4 & 18,8 \\
\hline 7 & Mikayla & 82 & 0,4 & 32,8 \\
\hline 8 & M. Abil & 82 & 0,4 & 32,8 \\
\hline 9 & Atthaya & 47 & 0,4 & 18,8 \\
\hline 10 & Afidatul & 65 & 0,4 & 26 \\
\hline
\end{tabular}

The normalization results of the growth criteria are obtained from the utility multiplication with the normalization results in the previous 2 stages.

Example of a case study on a toddler (Adam)

Results $=65 \times 0,4=26$

Meanwhile, the results of the search for the utility of developing criteria in table 13 will be used to find the normalization value of the developing criteria of each toddler. The results of normalization can be seen in table 15 .

TABEL XV

DEVELOPING CRITERIA RESULTS

\begin{tabular}{|c|l|c|c|c|}
\hline \multirow{2}{*}{ No } & \multirow{2}{*}{ Name } & \multicolumn{3}{|c|}{ Developing Criteria } \\
\cline { 3 - 5 } & & Utility & Normalization & Results \\
\hline 1 & Adam & 89 & 0,6 & 53,4 \\
\hline 2 & Rida & 100 & 0,6 & 60 \\
\hline 3 & Syafira & 89 & 0,6 & 53,4 \\
\hline 4 & Arvino & 89 & 0,6 & 53,4 \\
\hline 5 & Malikha & 89 & 0,6 & 53,4 \\
\hline 6 & M. Gibran & 89 & 0,6 & 53,5 \\
\hline 7 & Mikayla & 89 & 0,6 & 53,4 \\
\hline 8 & M. Abil & 89 & 0,6 & 53,4 \\
\hline 9 & Atthaya & 89 & 0,6 & 53,4 \\
\hline 10 & Afidatul & 78 & 0,6 & 46,8 \\
\hline
\end{tabular}

The normalization results of the developing criteria are obtained from the utility multiplication with the normalization results in the previous 2 stages.

Example of a case study on a toddler (Adam)

Results $=89 \times 0,6=53,4$

5) Search the final result of the SMART method

Last step, find the final result of the SMART method. Each toddler will be searched for the final results to get an output rating for toddlers. The final results can be seen from the table 16.

TABEL XVI

FinAl RESUlts Of THE SMART METHOD

\begin{tabular}{|c|l|c|c|c|}
\hline No & Name & $\begin{array}{c}\text { Growth } \\
\text { Criteria } \\
\text { Results }\end{array}$ & $\begin{array}{c}\text { Developing } \\
\text { Criteria } \\
\text { Results }\end{array}$ & $\begin{array}{c}\text { Final } \\
\text { Results }\end{array}$ \\
\hline 1 & Adam & 26 & 53,4 & 79,4 \\
\hline 2 & Rida & 32,8 & 60 & 92,8 \\
\hline 3 & Syafira & 26 & 53,4 & 79,4 \\
\hline 4 & Arvino & 32,8 & 53,4 & 86,2 \\
\hline 5 & Malikha & 32,8 & 53,4 & 86,2 \\
\hline 6 & M. Gibran & 18,8 & 53,5 & 72,2 \\
\hline 7 & Mikayla & 32,8 & 53,4 & 86,2 \\
\hline 8 & M. Abil & 32,8 & 53,4 & 86,2 \\
\hline 9 & Atthaya & 18,8 & 53,4 & 72,3 \\
\hline 10 & Afidatul & 26 & 46,8 & 72,8 \\
\hline
\end{tabular}

From the table above, it can be seen that the final result of a toddler with the name Adam is 79.4. These results are obtained from the sum of the results of the growing criteria of 26 and the results of the developing criteria of 53.4.

\subsection{Decision Support System Classification Results}

The final results of each toddler in table 16 will be sorted from the highest score to the lowest score. After sorting the final results, then a ranking will be given to toddlers from 1 onwards. While the results of the calculation of the classification of each toddler from table 9 will be taken the final result in the form of active or inactive status. For more details can be seen in figure 3 .

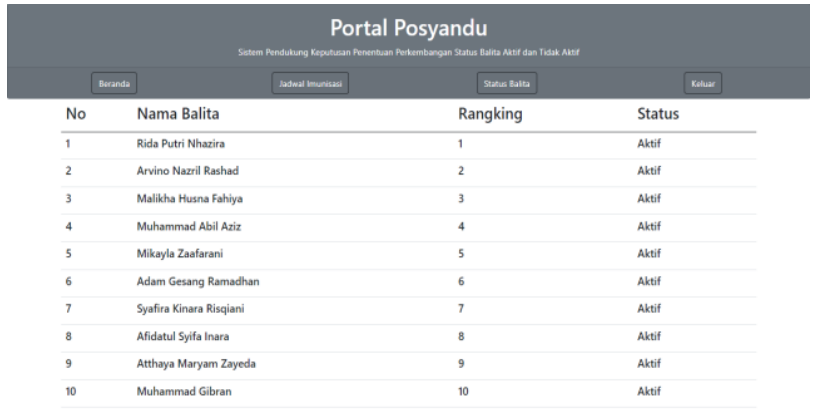

Figure 3. Toddler Status Page

From figure 3 of the decision support system above, it can be seen that the toddler with the name Adam is ranked sixth with active status.

\section{CONCLUSION}

The application of a decision support system for determining the developmental status of children under five during the posyandu uses the Naive Bayes Classifier and Simple Multi Attribute Rating Technique (SMART) method, which is a website-based application designed specifically for posyandu cadres. This application is useful in helping 
posyandu cadres in determining the developmental status of toddlers at the posyandu based on growth and development criteria.

The final result of this decision support system is in the form of a decision on the development of the status of active or inactive toddlers in toddlers and ranking of toddlers as seen from the highest average SMART score. The results of the decision on the developmental status of toddlers can help cadres in analyzing the development of toddlers with the aim of creating a better generation of toddlers. Based on the calculations that have been carried out in this study, the toddler with the name Adam resulted in the sixth rank and classification with active status.

\section{REFERENCE}

M. H. I. Fahmi and I. H. Al Amin, "Best Products with TOPSIS Method and Sales Forecasting with Weighted Moving Average," J. Appl. Informatics Comput., vol. 4, no. 2, pp. 116-123, 2020.

[2] R. Hidayatillah, M. Mirwan, M. Hakam, and A. Nugroho, "Levels of Political Participation Based on Naive Bayes Classifier," IJCCS (Indonesian J. Comput. Cybern. Syst., vol. 13, no. 1, pp. 73-82, 2019.

[3] M. R. Wijaya, R. Saptono, and A. Doewes, "The Effect of Best First and Spreadsubsample on Selection of a Feature Wrapper With Naive Bayes Classifier for The Classification of The Ratio Inpatiens," Sci. J. Informatics, vol. 3, no. 2, pp. 41-50, 2016.

[4] A. Wahana, C. N. Alam, and S. N. Rohmah, "Implementation of the Simple Multi Attribute Rating Technique Method (SMART) in Determining Toddler Growth," J. Online Inform., vol. 5, no. 2, 2020.

[5] D. Borissova and D. Keremedchiev, "Group decision making in evaluation and ranking of students by extended simple multi-attribute rating technique," Cybern. Inf. Technol., vol. 19, no. 3, pp. 45-56, 2019.

[6] J. Nakhaei, M. Bitarafan, S. Lale Arefi, and O. Kapliński, "Model for rapid assessment of vulnerability of office buildings to blast using SWARA and SMART methods (a case study of swiss re tower)," J. Civ. Eng. Manag., vol. 22, no. 6, pp. 831-843, 2016.

A. T. P. Utari, M. Yamin, and L. Surimi, "Sistem Pendukung Keputusan Penentuan Status Gizi Buruk Dan Rekam Medik Pada Balita Dan Ibu Hamil Menggunakan Metode Simple Multi-Atribute Rating Technique," semanTIK, vol. 3 , no. 1 .

[8] N. Hayatin, G. I. Marthasari, and L. Nuarini, "Optimization of Sentiment Analysis for Indonesian Presidential Election using Naïve Bayes and Particle Swarm Optimization," J. Online Inform., vol. 5, no. 1, pp. 81-88, 2020.

[9] R. I. Hapsari, B. A. I. Sugna, D. Novianto, R. A. Asmara, and S. Oishi, "Naïve Bayes Classifier for Debris Flow
Disaster Mitigation in Mount Merapi Volcanic Rivers, Indonesia, Using X-band Polarimetric Radar,” Int. J. Disaster Risk Sci., vol. 11, no. 6, pp. 776-789, 2020.

[10] S. Rahayu and A. S. RMS, "Penerapan Metode Naive Bayes Dalam Pemilihan Kualitas Jenis Rumput Taman CV. Rumput Kita Landscape," Digit. Zo. J. Teknol. Inf. dan Komun., vol. 9, no. 2, pp. 162-171, 2018.

[11] N. Widyaningsih, B. P. K. Bintoro, and R. H. Renggah, "The choice of district road construction by the method of analytical hierarchy process and simple multi attribute rating technique," Int. J. Eng. Technol., vol. 7, no. 4, pp. 2213-2217, 2018. 